\title{
Travelling Across Borders: Temporality, Trauma, and Memory in Amitav Ghosh's Dancing in Cambodia and At Large in Burma
}

\author{
Hariom Singh \\ Ph.D. Assistant Professor, Department of English, Babasaheb Bhimrao Ambedkar \\ University, Satellite Campus, Amethi (UP).Email: h.singh765@gmail.com
}

\begin{abstract}
In travel writing as a genre, the convergence of the words temporality, memory and trauma has occasioned an explosion of deliberations centred around the representation of the other(ness), the privilege of speaking of and for a foreign culture, and strategies used to perpetuate hierarchies and differences in cultural discourses. From having strong cultural affinities with Greater India in the ancient past, the countries of Southeast Asia like Cambodia, Myanmar have undergone sea changes in the present experiencing a long phase of colonisation and then ravaged by their own internal strife and upheavals. Writers from the erstwhile colonised countries like Amitav Ghosh have attempted in their travelogues to document the history and culture of Cambodia and Myanmar while traversing its rough terrain. Amitav Ghosh's widely acclaimed Dancing in Cambodia and At Large in Burma stands as the foremost example for understanding the travails of time and history of Cambodia and Myanmar. The narration of Ghosh's travel experiences in these countries brings to the fore the complex temporal dimensions of history amalgamated with collective trauma caused to its people through seemingly unabated and intense phases of violence and bloodshed in Khmer Rouge revolution. The proposed paper explores the various couplings of history and memory to explore the perennial traumatic feeling of the people of Myanmar and Cambodia and attempts to locate it in a larger historical perspective generally shared with India. Some pertinent questions which the proposed paper seeks to reflect upon are: the dangers of homogenisation and using ahistorical vocabulary to replicate the hegemony of cosmopolitan models of postcoloniality over local models. Also, is 'out of placeness' of the narrator is a problematic identity or something permanent and worth celebrating? Is cosmopolitanism suitable for postcolonial societies or is it just another totalising discourse of colonialism spreading its tentacles in complicity with neo-liberalism?
\end{abstract}

Keywords: Memory, Travel, Trauma, Cosmopolitan

\section{Introduction}

Within the realm of human experiences, travel is a primordial activity which creates memories for us, some of which are unforgettable and transform us to such an extent that we no longer remain what we are. Every time one crosses borders and leaves his footprints behind, one experiences the world through fresh eyes and reads one more page from the book of this world. Indian travel writers in recent times have emerged as prime chroniclers of such memories. Writers like Pankaj Mishra, Rahul Sankrityayan, Vikram Seth, and others in the recent past have penned some of the finest specimens of travel narratives and have enriched the genre in various ways.

(C) AesthetixMS 2020. This Open Access article is published under a Creative Commons Attribution Non-Commercial 4.o International License (http://creativecommons.org/licenses/by-nc/4.o/), which permits non-commercial re-use, distribution, and reproduction in any medium, provided the original work is properly cited. For citation use the DOI. For commercial re-use, please contact editor@rupkatha.com. 
Travelogues have been a primary source to gather information about Southeast Asia. Europe's knowledge of Southeast Asia which appeared at the beginning of the Enlightenment in the 16th century was mainly from the writings and maps of the Portuguese and Spanish travellers and later on in the 17th century through the Iberian and Dutch. These travelogues document and describe the manners, customs, and people of Southeast Asia predominately for the Western audience. As the political and commercial interests of various European imperial powers spiked in the region due to the spice trade, migration from Europe also gained momentum with state support and individual enterprise. The consequent colonisation left the culture of the region drastically altered and increasingly diverse. It was in this context that travelogue writers set out to explore Southeast Asia.

Travel writing thus emerged as a distinct genre of writing during the nineteenth and twentieth century to examine cultural, political, and social change in Southeast Asia. Among the contemporary practitioners of this genre, intrepid traveller and erudite scholar Amitav Ghosh stands at the forefront. He is the representative of a new group of travel writers who have exhibited a keen interest in the emerging socio-political and cultural identities in Southeast Asia. Amitav Ghosh's exploration of Southeast Asia acknowledges the millennia-old indelible prints which India and its people have left on its rich cultural heritage. In an interview given to Kyaw Phyo Tha in 2012, Ghosh stated:

India's influence in Southeast Asia was never a military influence, or political influence even. But it was the influence of stories like Ramayan and Mahabarata. Throughout Southeast Asia, throughout Asia, they became such important cultural forms. It happened not through power, not through politics. It happened through stories. In a sense, I think you could say we are doing what our ancestors did-telling stories. That's one thing we are good at.

Ghosh's preoccupation with the Southeast Asian region is not new. As travel happens to be a recurring trope in his works, his predilection for borders and their role in shaping our memories is substantial. One of his earlier novels The Glass Palace (2000) was set against a combined backdrop of India and the Southeast Asian countries- Myanmar and Malaysia. In the words of Quintus Curtius his travelogues can be categorised as personal discovery where "the author visits a certain place, or makes some sort of journey, and in the process makes profound observations about himself or his locale. The goal here is not so much to impart information about the placed traveled in; the goal is to explore deeper psychological or moral themes" (Curtius, 2015).

In the nineteenth and the twentieth century, Southeast Asia found an extensive expression in the travelogues of some famous novelists from Europe e.g. Rudyard Kipling's Letters of Travel, Part I (1920), W Somerset Maugham's The Gentleman in the Parlour (1935), and more. Such writers in the words of Edward Said helped in institutionalising "discourses through which "the West" exoticized, defined, and ultimately dominated "the East," thereby dichotomizing the world into two unequal realms." (Said, 2003, p. 12). Ghosh's travel essays offer a counter-hegemonic discourse by problematising the use of antiquated opinions and imperial myths in the travelogues of such writers. These essays equip us with new epistemological codes to traverse through the unfamiliar, uncharted, never seen before the territory of Cambodia and Myanmar. In her seminal work on travel writing, Mary Louise Pratt writes about an "estheticist or literary vein of scholarship. . . in which travel accounts, usually by famous literary figures, are studied in the artistic and intellectual dimensions ... "(Pratt, 1992, p. 10) and it is in this sense Ghosh's travelogues need to be studied. 
Amitav Ghosh's travelogue Dancing in Cambodia and At Large in Burma (1998) comprises three essays namely "Dancing in Cambodia," "Stories in Stone," and "At Large in Burma" which he wrote based on his visit to the Southeast Asian countries of Cambodia and Myanmar in 1993 and 1995-96. These essays are a faithful and sincere record of his personal experiences while travelling in these two countries. They acknowledge the distinctive cultural and historical importance of Southeast Asian countries and explore their present situation from a variety of perspectives.

This paper is divided into two parts: the first part deals with the two essays namely "Dancing in Cambodia" and "Stories in Stone" which focus on Cambodia of the post- UNTAC election years and the second part analyses the third and final essay "At Large in Burma." It brings to the fore the various couplings of history and memory over time to explore the perennial traumatic feeling of the people of Cambodia and Myanmar and attempts to locate it in a larger historical perspective widely shared with India. Some pertinent questions which the paper reflects upon are: the dangers of homogenisation and using ahistorical vocabulary to replicate the hegemony of cosmopolitan models of postcoloniality over local models. Also, is 'out of placeness' of the narrator a problematic identity or something permanent and worth celebrating?

The two essays "Dancing in Cambodia" and "Stories in Stone" reflect on the traumatic nature of Cambodian history following the systematic attempts to destroy it by the xenophobic Khmer Rouge regime (1975-79) and the subsequent endeavours of the Cambodian people after the 1993 general elections to revive their lost and forgotten cultural heritage. In these essays, one notices a significant variation upon the way conventional travelogues are conceived and written as Ghosh incorporates the personal testimonies of the survivors of the Khmer Rouge (also called the Pol Pot regime named after its leader Pol Pot) genocide. His travel is not just to certain places (Cambodia) but also into the history of these places. The act of remembering the past is what Ghosh shares with other people whom he meets on his way thus participating in a collective remembering of the injured past of modern-day Cambodia. Paul Ricoeur in his influential treatise on memory writes:

From such shared memories we pass by degrees to collective memories and its commemoration linked to places consecrated by tradition. It is the occurrence of such experiences that first introduced the notion of 'sites of memory', ... . [ $t$ ] he spatiality that geography sets in parallel with the temporality of history is the one suggested by a phenomenology of place or site. (Ricoeur, 2004, p. 149)

By linking the history of the land with individual memories of its peoples, Ghosh insists on imaginative writing of Cambodian history, the one which will add up and explore more possibilities instead of thwarting them for acts of memorisation involve multiple possibilities, more significantly the ones which an individual wants not to occur. Ricoeur opines that history is reductive in nature for its writing pre-supposes the existence of a narrative. Ghosh by including individuals' memories, personal testimonies in documenting his travels explores the reality of the Cambodian past rather than just its facticity. Those who aid him or the ones whom he meets in the course of his travels are not enervated beings hopelessly struggling to come to terms with their past rather they are "capable human beings: being able to speak, being able to intervene in course of affairs, being able to recount" (Ricoeur, 2004, p. 26). The centrality of Phnom Penh (the capital city of Cambodia) in the travel essays of Ghosh is of great significance for it is intimately linked to the collective memories of its people. The city of Phnom Penh "brings together in the 
same space different ages, offering to our gaze a sedimented history of tastes and cultural forms" (Ricoeur, 2004, p. 151) thus linking the temporality of history with the spatiality of space.

Cambodia's history has been marked for centuries by violence, with perpetrators coming from within and beyond its borders. In particular, the genocide and mass displacement of people during the Khmer Rouge years from 1975-79 left a permanent scar on the collective imagination of Cambodian people with its innumerable memories of violence. In 1992, after a prolonged spell of civil war which had erupted immediately after the demise of the Pol Pot regime, general elections were conducted under the supervision of the United Nations Transitional Authority (UNTAD) in Cambodia. A democratically elected and stable government was installed and Cambodia "which was like a shattered slate" (Ghosh, 2002, p. 246) turned in the post-election years to the revival of its own ancient cultural heritage through dance, music, and architecture. The traumatic memories of people's mass displacement and genocide by Pol Pot and his allies have become a compelling part of the Cambodian past. It can be argued that a conventional approach to history writing is insufficient to deal with the traumatic effects of the past. In the words of Urvashi Butalia "if there is a way in which people's stories, notwithstanding all their problems, can somehow expand, stretch the definitions and boundaries of history and find a place in it. Is there some way in which history can make space for the small, the individual voice?" (Butalia, 1998, p. 13). Ghosh talks freely to these survivors and thus their "tales of the horror and brutality, the friendship and sharing, are told and retold between communities, families and individuals." (Ricoeur, 2004, p. 10).

In "Dancing in Cambodia" Ghosh retells the story of Cambodian king Sisowath's visit to the French city of Marseilles in 1906 to participate in Exposition Coloniale "an immense fairy land of an exhibition centred on the theme of France's colonial possessions" (Ghosh, 2002, p. 37). The entourage of the king had a royal troupe of dancers "dressed in colourful sampots" under the guardianship of king's eldest daughter princess Soumphady (Ghosh, 2002, p.66).These dancers were much renowned in France and other European countries for their art and the onlookers at Marseilles port were completely taken aback by their fabulous appearance whose manners and ways surpassed their expectations. Ghosh's conversation with Chea Samy, a sister-in-law of Pol Pot and a teacher at the School of Fine Arts in Phnom Penh, serves to reveal the twofold purpose of King Sisowath's story in the essay. Firstly, it exposes the sanctimonious nature of European imperial powers towards the subjects of their colonies/protectorates and secondly, how fatal proved to be the lessons which King Sisowath proclaimed to have drawn from his trip to France. After his return, King Sisowath issued a letter to the effect that "emulation is the only means of turning resolutely to the path of progress" (Ghosh, 2002, p. 594). Incorporation of his insights into the imitation of French in state policies caused irreparable damage to the glorious and ancient heritage of Cambodia. His fascination with French customs and manners led him to establish a school named College du Protectorat on the French model of education and during Khmer Rouge years, many of the nearest allies of Pol Pot were a graduate of this school. This institution played a vital role in popularising and institutionalising the communist ideology in Cambodia.

In the essay "Stories in Stone," Ghosh explores the paradoxical nature of Angkor Wat as a historical monument which encompasses in itself the history of cultural contacts since ancient times between Cambodia (erstwhile Khmer), one of the first countries in South East Asia to have received the Indian influence and India. The temple "a monument to the power of story" narrates the memories of Cambodia's cultural heritage in a way no other monument can. Angkor's rediscovery as a result of French attempts marks the colonial turn in the re-fashioning of the Cambodian-Khmer identity. After independence, it fell into a general decline during the Pol Pot 
regime. Underlining the paradoxical role of Angkor Wat in Cambodian history, Ghosh remarks that though Angkor Wat is a temple "but it never figures in anything to do with religion or indeed in any context which might be called traditional or old fashioned" (Ghosh, 2002, p. 789). In a country like Cambodia which had a prominent presence of Hinduism on its soil for several centuries, it is surprising that Buddhist temples or pagodas built later don't allude to Angkor Wat. The testimony of Ven Luon Chun brings to the fore how the Buddhist pagoda on the premises of Angkor Wat came to acquire its present site at the directions of the French archaeologists. Also, during the Khmer Rouge, many Buddhist monks living in the monastery were killed and those who remained were taken to camps for work. Chun was called again after the fall of Pol Pot to attend to the temple during its restoration process.

The two essays are united by a quest of the Cambodian people to recover from their traumatic past of the Khmer Rouge regime (1975-79). Through the testimony of various survivors of the Pol Pot regime, Amitav Ghosh takes into account the emotional ramifications of the event. In fact, in its narrative, it encompasses twin strands of realistic/journalistic and psychological study in the victimhood of those who survived the Pol Pot years.These essays reread the mainstream academic history from the point of view of those afflicted and problematise the flimsy boundary between oral and written histories.

Ghosh in his conversation with Molyka, a civil servant remembering the Khmer Rouge years, draws an interesting parallel between the Naxalist insurgency in some parts of India and the violence unleashed by different warring communist groups in Cambodia. The common people of Cambodia were terror-struck due to the sheer brutality of the violence and chaos into which the entire country had descended and their natural rights were brutally trampled upon. He writes that "Cambodia's was not a civil war in the same sense as Somalia's or the former Yugoslavia's fought over the fetishism of small differences. It was a war on history itself, an experiment in the reinvention of society. No regime in history had ever before made so systematic and sustained an attack on the middle class." (Ghosh, 2002, p. 149) The memories of laceration which have come to terribly haunt the people of Cambodia provide the survivors, sites of engagement with history in the present. Cathy Caruth in her "Unclaimed Experience: Trauma, Narrative, and History" echoes that narratives of trauma should be read,

... not as the story of the individual in relation to the events of his own past, but as the story of the way in which one's own trauma is tied up with the trauma of another the way in which trauma may lead, therefore, to the encounter with another, through the very possibility and surprise of listening to another's wound. (Caruth, 1996, p. 8)

A testimony, argues Ricoeur, is a representation of the past "through narrative, rhetorical devices, and images" (p. 161) and the attestation of the past through it involves "an autobiographically certified narrative of a past event, whether this narrative be made in informal or formal circumstances" (Quoted in Ricoeur 43). Ghosh's narration of the Cambodian history tries to address the omissions of individual histories of oppression and marginalization at the hands of the Pol Pot regime in the formal discourses. Such omissions are deliberately made to preserve the overall national narrative of a moral, faithful, and civilized country. The spaces where the survivors found protection and care were once the sources of anxiety and fear instead. It is the iterability of testimony which renders it amenable to creative usage in the hands of writers like Ghosh: "Thanks to a reiterable character that confers upon it the status of institution, testimony can be taken down in writing, deposited" (Ricoeur, 2004, p. 167). 
In contemporary travel literature, the traumatic past influences the present struggles of working through the long-hidden events of that past while embracing modernity and the separation from those past events. Relation to the past is strictly not a relation to one's own past but to social history and its material and institutional effects. This is particularly true for Cambodia, where history, particularly that of the Pol Pot years, is still actively influencing the present: "Terror was essential to their exercise of power not merely of their coercive machinery, but of the moral order on which they built their regime." (Ghosh, 2002, p. 715). At a deeply psychological level, the mammoth task which lies ahead for Cambodia as an imagined community is to recover from the trauma of the past and to reconstruct the country ravaged during the civil war years. Suppaya Helene Nut, in one of her articles summed up the repercussions of the Pol Pot regime which decimated the legacy of Khmer dance:

Like all forms of Cambodian culture, the Royal Ballet was banned during that time. The hardship, loss, and terror was shared by all the people, but artists of the Royal Ballet were among those particularly hard hit because of their ties to the Royal Court. After the collapse of the regime in 1979, only ten percent of these artists had survived. The trauma to the population as a whole was immense... (Nut, 2017, p. 43)

In the early 1990s, sincere efforts were made to restore the forgotten/eroded past of Cambodia through re-membering of music, dance, and architecture.

Memories have a strange way of operating on the past. Svetlana Boym argues that a nostalgia for the past which helps in recuperation is reflective in nature as against the restorative nostalgia which "dwells on loss, ruins and dreams and acknowledges imperfection" while thriving on the hope of human understanding and survival" (quoted in Walder, 2009, p. 940). Thus, Angkor Wat as embodied memory in the years during which Cambodia rebuild itself has come to symbolise the modernity of the nation in the age of science and technology. Angkor Wat can be read as archi(text)ure which reflects the eclecticism of historical and cultural relations between India and Cambodia since ancient times and has witnessed centuries of peaceful coexistence of Hinduism and Buddhism before Cambodia eventually embraced Buddhism. The revival of 'archives of memory' through the royal Khmer dance and the temple of Angkor Wat represent spatio-temporal continuity of memories in the present to shape the nationhood of Cambodia. Such attempts aimed at revival also underscore the individual and communal attempts of resistance against the state to erase the memories of trauma which it finds threatening to its stability. Re-imagining of national identities through re-staging of the past involves "create[ing] an experience of the past that seeks to overcome historical and economic ruptures." (Agnew, 2007, p. 300)

In recent years the greatest challenge which the revival attempts have faced has come from Globalisation. Globalisation's tendency to annihilate a culture's distinct identity and turn the specifics of local into the universals of global is posing a grave threat to the restoration of cultural forms in erstwhile colonies like Cambodia. The indiscriminating forces of Globalisation are fast eroding the differences between various local cultures. Nevertheless, the liberating practices of history should not be written off under the impact of Globalisation. There can be other possible ways through which history can be animated by memory and thus a rereading of the past should be such that which enables the societies to heal their trauma. It is not a matter of choosing one over the other. Rather, the two components of temporality should work together actively which results in the inception of critical historical consciousness which is capable of selfintrospection from the perspective of its other i.e. memory. 
All the three essays revolve around a central experience of trauma that echoes through the diegetic order of Ghosh, each negotiating history and memory in a different way. The third and final essay of the collection "At Large in Burma" is an attempt to understand the social and political situation of Burma (modern Myanmar) which prevailed through much of the 1990s. Ghosh's concern in this essay appears to have moved beyond the exploration of just traumatic and painful memories of people to wider concerns of democracy and its future in strife-torn Burma and poses some relevant questions: "what is Burma (or Myanmar for that matter)? What does it mean to use a single name for an entity that has been divided against itself for much of its contemporary history?" (Ghosh, 2002, p. 1190). Ghosh dives deep into the political history of Burma, an Indian province under the British colonial rule until 1947 through the personal memories, conversations, and testimonies of his acquaintances, co-travellers and political dissidents. He, in the words of Gabriel, is searching for "a disorder in the relationship between memory and past experience [which] is, at a minimum, an important component of trauma's etiology" (Gabriel, 2009, p. 1). A sizeable part of the essay is dedicated to the precarious political existence of Suu Kyi, a renowned political leader and face of the democratic forces in militaryruled Burma.

Myanmar's history is beset with violence since its independence from the British colonial rule in January 1948. After the assassination of General Aung San, the country plunged into ethnic struggles and following a military coup "when Gen Ne Win, the chief of the army abruptly took control of the army and suspended the government" (Ghosh, 2002, p. 1011) in 1962, it is constantly under the military dictatorship. The common people of multi-ethnic Myanmar have lived in a state of perennial trauma since the coup. In the words of Kong Sarith "since 1962, we have lived through the dark ages... torture, murder, poverty" (Ghosh, 2002, p. 1077). Every decade has seen its own generation of activists and democracy supporters. However, Ghosh's travel essay is more concerned with the pro-democracy movements which emerged in 1988 and have continued since then. In the ensuing struggles, thousands of protestors were killed and the democratic and human rights of the Burmese people were brutally assaulted upon. The personal narratives which Ghosh comes across reveal the intricate nature of Burmese society and the ongoing civil war along with the fragmented nature of most of the contemporary history of Burma as against the relatively stable history of Cambodia. These memory narratives not only highlight the traumatic pathetic situation of political dissenters living in perpetual incarceration but also serve to support multiple discourses concerning the political situation in Burma. It brings to the fore the political consequences of how the victims of trauma construct fluid narratives of their fragmented identity.

The political use of trauma narratives whether in social or human rights movements is recognized. It is through Suu Kyi's, the youngest daughter of the assassinated leader Aung San life story, that countries around the globe have awakened to the grim political realities of Burma. Suu Kyi's confinement in her own house garnered more popularity and brought legitimacy to the prodemocracy movement. "Pure light of hope" as she came to be commonly regarded (Ghosh, 2002, p. 1185), her life-story due to the injustices meted to her by SLORC come to be seen as one of good versus evil, of a lone woman combating against the military dictatorship.

Ghosh writes at length about his own attempts to interview Suu Kyi and his subsequent reflections on the political-military turmoil in Burma after having interviewed her. As the daughter of Aung San, the Burmese independence hero, Aung San Suu Kyi was able to command the respect of the Burmese people and came at the forefront of the democracy movement having gained encouragement by university students. In the 1990 election, the opposition party, National 
League for Democracy (NLD) won 392 seats out of 485 seats due to the unprecedented popularity of Suu Kyi. When she won the Nobel Prize in 1991, her place in the Western consciousness was assured. The public sharing of personal traumas can be put to performative uses as in case of activist-leaders like Suu Kyi where the western audience in particular have grown accustomed to her perceiving the public sharing of personal traumas as cathartic and a significant step in healing the collective trauma of Burma as a nation and/or community.

In the context of exiles, there are intricate nuances attached to the narrative construction of trauma and its related performance. His visit to Karenni hinterland and conversations with Sonny, a student turned Karenni insurgent, the highest in command Mr. Aung Than Lay and his immediate next Mr. Htoo, reveals how alternative stories of personal and communal loss escape our attention. The Karenni stories of loss and trauma which have their origins in Burmese colonial history directly confront the power relations between mainstream pro-democracy activists and the ethnic minorities of Burma living at the fringes of the Burmese community. Ghosh thus focuses on not only the mainstream but also on the alternative stories thus resisting the hegemonizing of certain trauma narratives recognising that "life is not text, not stories, but rather performance of stories." (Kennedy \& Wilson, 2003, p. 132) Sharing of trauma narratives of "enforced adaptation to nomadism" (Ghosh, 2002, p. 1310) has a "special, double connotation: it contains objective, judicial, public and political aspects as well as subjective, spiritual, cathartic and private aspects" (Agger, 1994, p. 9). In all the cases discussed in the essay, the trauma survivors make it a point that their narrative texts act as the basis for the political mobilisation of their community members. It is this aspect that binds the Karenni refugees into "a cause, an archive, an economy" from being just "an army and a gathering of camp followers." (Ghosh, 2002, p. 1362).

Memories are objects that tumble out unexpectedly from the mind, linking the present with the past. Memories or collective memories can represent ways that we believe our present society is or ways that our present society should be -- a depiction of the present or the future. Elaborating the relation between collective memories and human society, Joseph M. Gabriel writes:

Narratives-whether in the form of personal testimony, documentary film, academic scholarship, or some other genre-both grow out of and inform the collective understandings of causation, responsibility, and obligation through which we, as a society, think about and respond to trauma. Trauma can thus be understood to operate not only at the individual level but also at the level of collective memory and social behaviour." (Gabriel, 2009, p. 1)

Ghosh's understanding of the Burmese chequered political condition has its own share conundrums. He concludes by saying that "all boundaries are artificial. There is no such thing as a natural nation, which has journeyed through history with its boundaries and ethnic composition intact. In a region as heterogenous as southeast Asia, any boundary is sure to be arbitrary. On balance, Burma's best hopes for peace lie in maintaining intact the larger and most inclusive entity that history albeit absent-mindedly, bequeathed its population almost half a century ago." (Ghosh, 2002, p. 1380). 


\section{References}

Agnew, V. (2007 September). History's Affective Turn: Historical Re-enactment and its Work in the Present. Rethinking History, 11(3), 299- 312. https://doi.org/10.1080/13642520701353108

Agger, I. (1994). The Blue Room: Trauma and Testimony Among Refugee Women - A Psycho - Social Exploration. London: Zed Books.

Butalia, U. (1998). The Other Side of Silence: Voices from the Partition of India. Penguin.

Caruth, C. (1996). Unclaimed Experience: Trauma, Narrative, and History. Baltimore: The Johns Hopkins University Press.

Curtius, Q. (18 March 2015). The Three Types of Travel Writing, And Their Uses. qcurtius. https://qcurtius.com/2015/03/18/the-three-types-of-travel-writing-and-their-uses/

Gabriel, J. M. (2009). Introduction: History, Memory, and Trauma.Traumatology,15(4), 14.https://doi.org/10.1177/1534765609356714

Ghosh, A.(2002).Dancing in Cambodia and Other Essays. Penguin. Kindle.

Kennedy, R. \& Wilson, T. (2003). Constructing shared histories: Stolen generations testimony, narrative therapy and address. In Bennett \&Kennedy (Eds.), World memory: Personal trajectories in global time (pp.119-139). Palgrave Macmillan.

Nut, S. (2017). The Khmer Dance Project. The Focus, (Autumn), 78.

Pratt, M. L.(1992). Imperial Eyes: Travel Writing and Transculturation. London: Routledge.

Ricoeur, P. (2004). Memory, History, Forgetting. Chicago: The University of Chicago Press.

Said, E. (1979). Orientalism. New York: Vintage.

Tha, Kyaw Phyo. (22 November 2012). Interview: The Glass Palace Revisited. Irrawaddy. https://www.irrawaddy.com/in-person/interview/the-glass-palace-revisited.html

Walder, D. (2009). Postcolonial Nostalgias: Writing, Representation, and Memory. Textual Practice,23(6), 935-946.

Hariom Singh is an Assistant Professor at Department of English, BBAU Satellite Campus, Amethi. He has his Ph.D. on the fictional works of Githa Hariharan from Department of English, Banaras Hindu University. His areas of research interest are Diaspora studies, gender studies and Indian English fiction. 